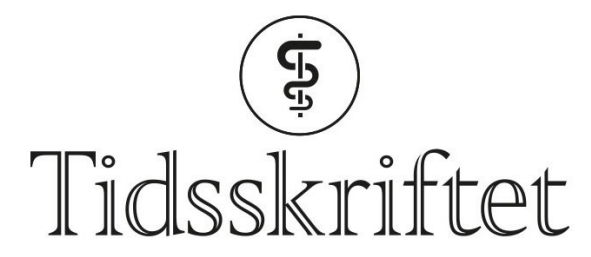

DEN NORSKE LEGEFORENING

\title{
Sink til barn med diaré
}

FRA ANDRE TIDSSKRIFTER

KRISTOFFER BRODWALL

Barne- og ungdomsklinikken

Haukeland universitetssykehus

Sinktilskudd anbefales til barn med akutt diaré i fattige land, men effekten er like god med en lavere dose enn tidligere anbefalt.



Illustrasjonsfoto: Shigemitsu Takahasi / Alamy Stock Photo

På verdensbasis er diaré fortsatt en av de vanligste dødsårsakene blant barn, selv om det har vært en markant nedgang av denne typen dødsfall de seneste tiårene. Det er anslått at en halv million barn døde av diaré i 2018. De fleste av disse dødsfallene kunne vært unngått med adekvat behandling; i første rekke peroral rehydrering.

Som behandling av diaré hos barn i lav- og mellominntektsland anbefales det i tillegg å gi sinktilskudd, fordi dette reduserer diaréen og forkorter sykdomsforløpet. Standard dose er $20 \mathrm{mg}$ sink per dag, men alternative doser hadde ikke blitt undersøkt før anbefalingen ble introdusert. Sinktilskudd har en metallisk smak og kan provosere frem oppkast. I en fersk studie ønsket man derfor å finne ut om lavere doser kan ha like god effekt og mindre bivirkninger (1).

Studien omfattet 4500 barn i alderen $1 / 2-5$ år med akutt diaré, halvparten i India og resten i Tanzania. Barna ble randomisert til å motta sinktilskudd på $5 \mathrm{mg}, 10 \mathrm{mg}$ eller $20 \mathrm{mg}$ per dag.

Etter fem dager hadde henholdsvis 7,2 \%, 7,7 \% og 6,5\% av barna fortsatt diaré. Forskjellene var under det som på forhånd hadde blitt definert som betydningsfullt. Det var heller ingen forskjell mellom gruppene i antall løse avføringer. Oppkast innen 30 minutter etter inntak av sinktilskuddet forekom hos henholdsvis 13,7\%, 15,6 \% og 19,3\%. Man kunne derfor fastslå at lavere sinkdoser ga mindre oppkast.

Alle dosene som ble brukt i studien, ligger over den daglige anbefalte dosen sink. Grunnen 
til at sink kan hjelpe ved diarésykdom, er ikke helt klarlagt, men mulige forklaringer kan være bedret immunrespons, spesielt hos barn som i utgangspunktet har sinkmangel og/eller hemmet klorutskillelse i tarmen.

LITTERATUR:

1. Dhingra U, Kisenge R, Sudfeld CR et al. Lower-dose zinc for childhood diarrhea - A randomized, multicenter trial. N Engl J Med 2020;383: 1231-41. [PubMed][CrossRef]

Publisert:30. oktober 2020. Tidsskr Nor Legeforen. DOI: 10.4045/tidsskr.20.0818

(C) Tidsskrift for Den norske legeforening 2020. Lastet ned fra tidsskriftet.no 